\title{
PEMETAAN PERUBAHAN EKOSISTEM WILAYAH PESISIR KECAMATAN DULLAH UTARA KOTA TUAL
}

\section{CHANGE OF COASTAL ECOSYSTEM MAPPING IN NORTH DULLAH SUBDISTRICT TUAL CITY}

\author{
Imanuel M. Thenu', Marvin M. Makailipessy ${ }^{2}$ \\ ${ }^{1,2}$ Politeknik Perikanan Negeri Tual \\ Korespondensi: i.m_thenu@yahoo.co.id
}

\begin{abstract}
The high-use activities, the lack of information and data on the ecosystem as a basic reference for management of coastal areas of the Subdistrict North Dullah. This study aims to determine the potential and distribution of major ecosystems and analyze the rate of change in a certain period of time based on image interpretation. Based on the results of image analysis will be known the extent and distribution of major ecosystems, are then compared with some of the imagery in the past period of time to analyze the rate of change. This research was conducted in the coastal region of North Dullah Subdistrict Tual City. The imagery analysis used the transformation of depth invariant index and supervised classification. Landsat 8 year 2014 image interpretation shows coral reef extents are 1934.82 hectares while for sea grass extents are 614.43 hectares. In 2004 to 2009 there was a increase in coral reef ecosystems extents to 133.56 hectares $(4.78 \%$ ), while for the seagrass ecosystem extents increase to 84.69 ha (14.58\%). In 2009 to 2014 coral reefs extent decrease to 992.16 hectares $(33.89 \%)$ while for seagrass extents decrease to 51.21 hectares $(7.69 \%)$.
\end{abstract}

Keyword: ecosystem, mapping, remote sensing, satelite imagery

\begin{abstract}
ABSTRAK
Tingginya aktivitas pemanfaatan serta kurangnya informasi dan data tentang ekosistem sebagai acuan dasar pengelolaan di wilayah pesisir Kecamatan Dullah Utara. Penelitian ini bertujuan mengetahui potensi dan sebaran ekosistem terumbu karang dan lamun serta menganalisis laju perubahannya dalam periode waktu tertentu berdasarkan hasil interpretasi citra. Berdasarkan hasil analisis citra akan diketahui luasan dan sebaran ekosistem, kemudian dibandingkan dengan beberapa citra pada periode waktu lampau untuk menganalisis laju perubahannya. Penelitian ini dilakukan di wilayah pesisir Kecamatan Dullah Laut Kota Tual. Metode analisis citra yang digunakan adalah teknik transformasi depth invariant indeks dan klasifikasi terbimbing. Hasil interpretasi citra Landsat 8 tahun 2014 menunjukkan luasan terumbu karang sebesar 1.934,82 ha sedangkan luasan lamun sebesar 614.43 ha. Pada tahun 2004 ke 2009 terjadi peningkatan luas ekosistem terumbu karang sebesar $133.56 \mathrm{Ha}$ (4.78\%), sedangkan ekosistem lamun terjadi peningkatan luas sebesar 84.69 ha (14.58\%). Pada tahun 2009 ke 2014 ekosistem terumbu karang mengalami penurunan luas sebesar 992.16 ha $(33.89 \%)$ sedangkan untuk ekosistem lamun mengalami penurunan luas sebesar 51.21 ha (7.69\%).
\end{abstract}

Kata kunci: citra satelit, ekosistem, pemetaan, penginderaan jauh

\section{PENDAHULUAN}

Pemanfaatan teknologi penginderaan jauh di Indonesia telah dilakukan dalam berbagai bidang mengingat penggunaan teknologi ini memiliki beberapa keuntungan yaitu dapat bekerja lebih cepat, biaya relatif murah dengan ketelitian memadai dan mengurangi kerja lapangan (Sirrajudin et al. 2010). Upaya pemetaan ekosistem terumbu karangyang berada di dasar perairan dangkal tidaklah mudah dilakukan secara teoritis
(Helmi et al. 2011). Lebih lanjut Helmi et al. (2011) mengemukakan bahwa penginderaan jauh satelit memberikan alternatif yang komprehensif untuk pemetaan ekositem perairan dangkal, seperti terumbu karang. Sensor penginderaan jauh dapat menembus perairan dangkal yang jernih dan mengenali karakteristik substrat dasar perairan tersebut. Liputan citra satelit yang sangat luas, akurat, resolusi spasial dan spektralnya tinggi, kemampuan perekaman ulang konsisten, akses data/citra satelit 
dan pengolahannya mudah, efisien dalam biaya dan tenaga operasional menjadikan penggunaan data dan metode ini menjadi sangat efektif.

Studi tentang penggunaan citra satelit landsat 8 untuk mendeteksi terumbu karang serta ekosistem di perairan dangkal telah dilakukan di indonesia antara lain: Pramudya et al. 2014 memetakan substrat dasar perairan dangkal dengan menggunakan kombinasi kanal 1, 2, 3, dan 4 pada citra landsat 8 dan menentukan kombinasi terbaik untuk memetakan substrat dasar perairan dangkal yang terbagi atas 4 kelas substrat di perairan Nusa Lembongan dan Nusa Ceningan Bali. Yulius et al. 2015 menggunakan satelit landsat 8 untuk memberikan informasi umum mengenai kondisi dan distribusi spasial tutupan terumbu karang di perairan Pulau Wangi-wangi, Wakatobi. Teguh dan Lingga, 2016 menganalisis perubahan luasan terumbu karang dengan menggunakan citra landsat 8 tahun 2014 dan 2015 di Pulau Menjangan, Bali. Penelitian lain yang berhubungan dengan deteksi perubahan habitat terumbu karang menggunakan citra landsat telah dilakukan oleh Wahidin et al. (2014) dengan menggunakan citra landsat 5 TM tahun 1996, Landsat 7 ETM+ tahun 2002 dan Landsat 8 tahun 2013 untuk mendeteksi perubahan habitat terumbu karang selama kurun waktu 2 dekade.

Kecamatan Dullah Utara memiliki 8 pulau, yang terdiri dari 3 pulau yang didiami yaitu Pulau Dullah, Pulau Duroa dan Pulau Rumadan serta 5 pulau yang tidak didiami yaitu Pulau Adranan, Pulau Sua, Pulau Bair, Pulau Mas dan Pulau Hadranan. Penduduk di Kecamatan Dullah Utara umumnya bermatapencaharian sebagai nelayan baik nelayan tangkap maupun nelayan budidaya. Berdasarkan data yang diperoleh dari Dinas Kelautan dan Perikanan Provinsi Maluku, jumlah nelayan sebanyak 1.262 yang didominasi oleh alat penangkapan ikan yaitu pancing diikuti alat tangkap sero dan bagan sedangkan jumlah pembudidaya yang ada di Kecamatan Dullah Utara pada tahun 2015 yaitu sebanyak 487 orang. Selain itu aktivitas lain yang berkembang di wilayah ini antara lain Pulau Bair dan Pulau Adranan sementara dikembangkan pemerintah daerah sebagai daerah tujuan wisata bahari sedangkan wilayah laut Pulau Mas dan Pulau Rumadan merupakan area yang dimanfaatkan pengusaha/swasta sebagai area budidaya mutiara.

Tingginya aktivitas pemanfaatan serta kurangnya informasi dan data tentang ekosistem di wilayah pesisir Dullah Utara menyebabkan pengelolaan belum dapat dilakukan secara optimal sehingga penelitian ini penting untuk dilakukan dalam memberikan informasi dasar yang berguna dalam menganalisis dan mengelola potensi sumberdaya wilayah pesisir dan lautan yang berkelanjutan.

Penelitian ini bertujuan untuk mengetahui sebaran dan luasan ekosistem terumbu karang dan lamun di daerah kajian berdasarkan hasil interpetasi citra, dan menganalisis laju perubahan sebaran dan luasan ekosistem terumbu karang dan lamun di daerah kajian dalam periode waktu tertentu berdasarkan hasil interpretasi citra. Manfaat dari penelitian ini adalah sebagai informasi dalam pengelolaan wilayah pesisir, khususnya sumberdaya pesisir yang telah mengalami degradasi untuk upaya-upaya rehabilitasi di masa mendatang.

\section{METODE PENELITIAN}

Penelitian berlangsung dari bulan Maret-Juli 2016. Lokasi penelitian bertempat di wilayah pesisir Kecamatan Dullah Utara Kabupaten Maluku Tenggara (Gambar 1).

Data yang digunakan dalam penelitian ini antara lain adalah data citra Landsat 5 TM hasil rekaman tanggal 24 Juli 2004 dan tanggal 26 Oktober 2009 serta data Citra landsat 8 OLI/TIRS Tanggal 27 Juli 2014. Ketiga data citra hasil perekaman Landsat ini dapat diperoleh atau diunduh dari USGS Earth Resources Observation and Science data centre (http://glovis.usgs. gov/). Tipe data citra satelit ini adalah Level $1 \mathrm{~T}$ yang secara sistematik telah terkoreksi geometrik (Terrain Corrected) dan diproyeksi ke sistem koordinat UTM zona 52S-WGS84. Data hasil pengukuran berupa data suhu, salinitas, kecerahan serta kedalaman. Data pengamatan visual uji akurasi citra yang diplotkan dengan menggunakan GPS. Studi literatur dilakukan untuk memperoleh data sekunder yang berkaitan dengan hasil penelitian.

\section{Metode analisis data}

Proses pengolahan dan analisis data dilakukan dalam 2 tahapan yaitu :

1. Pemetaan luasan dan sebaran ekosistem dilakukan pada citra landsat 8 OLI/ TIRS tahun 2014 menggunakan kanal 1, kanal 2, kanal 3 dan kanal 4 (pemisahan laut dan darat). Pemetaan karakteristik 
dasar perairan dilakukan dengan mentransformasikan kanal biru dan hijau menggunakan algoritma "depth invariant index", dengan persamaan yang mengacu pada LIPI (2014) yaitu :

\section{$Y=\operatorname{Ln~Kanal} i-(k i / k j) \operatorname{Ln~Kanal} j$}

Dimana Y adalah indeks dasar perairan dan $\mathrm{ki} / \mathrm{kj}$ adalah koefisien atenuasi. Perhitungan nilai koefisien atenuasi untuk ketiga citra tersebut terlihat pada Tabel 1. Sebelum dilakukannya proses klasifikasi, citra hasil transformasi kemudian dikombinasikan menggunakan palet warna pelangi maka objek pasir yang bercampur dengan pecahan karang akan terlihat dengan warna kuning, pasir halus akan terlihat dengan warna merah tegas, lamun akan terlihat dengan gradasi warna kuning hingga merah yang menunjukkan tingkat kerapatan tutupan lamun. Sedangkan objek karang, warna akan terbagi menjadi 3 macam warna yaitu hijau, cyan dan biru (Sulma \& Winarso 2003). Klasifikasi terbimbing merupakan proses pengelompokkan piksel pada citra menjadi beberapa kelas tertentu berdasarkan pada statistik sampel piksel (training) atau region of interrest (daerah uji) dalam hal ini digunakan sampel daerah uji berdasarkan pengelompokkan pada palet warna yang ditentukan oleh pengguna sebagai acuan, yang selanjutnya digunakan oleh komputer sebagai dasar untuk melakukan klasifikasi. Uji validasi di lapangan dilakukan untuk mengamati kondisi nyata lapangan dengan cara melakukan pengecekan silang dengan hasil klasifikasi dari citra satelit. Nilai ketelitian uji merupakan nilai rata-rata dari hasil uji validasi yang sesuai dibagi dengan jumlah sampel yang diperoleh.

2. Langkah yang sama pada tahap 1 kemudian dilakukan untuk citra landsat 5 TM tahun 2004 dan 2009 untuk mengetahui luasan dan sebaran ekosistem terumbu karang dan lamun. Laju perubahan luasan dihitung dengan mengacu pada persamaan Dewanti (2003) yaitu :

$$
\Delta L=(L t 2-L t 1) / L t 1 \times 100 \%
$$

Dimana : $\Delta L$ adalah Laju perubahan luas (\%), Lt1 adalah luas pada tahun pengamatan pertama (ha), Lt2 adalah Luas pada tahun pengamatan berikutnya.

Pengolahan data dan analisis citra dilakukan dengan menggunakan perangkat lunak ENVI 5, layout peta digunakan perangkat lunak QGIS 2, serta perangkat lunak office untuk menghitung koefisien atenuasi dan laju perubahan.

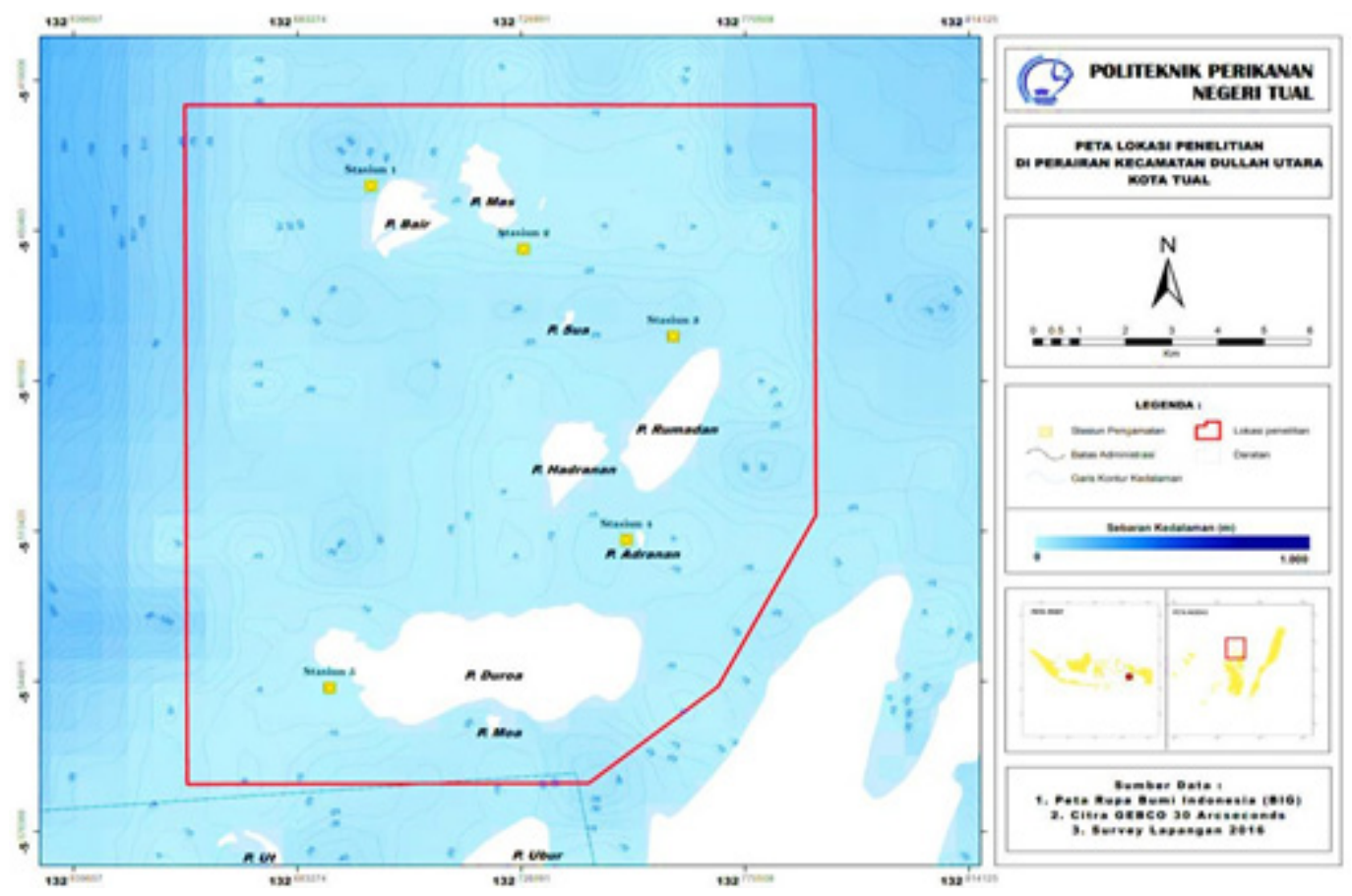

Gambar 1. Peta lokasi penelitian 
Tabel 1. Hasil perhitungan koefisien atenuasi untuk menentukan persamaan algaritma dari ketiga citra Landsat

\begin{tabular}{lcc}
\hline & ki/kj & Indeks dasar perairan (Y) \\
\hline Landsat 5 TM (2004) & 1.03 & $\mathrm{Y}=\ln$ Band $1+1.03^{*} \ln$ Band 2 \\
Landsat 7 +ETM (2009) & 0.89 & $\mathrm{Y}=\ln$ Band $1+0.89^{*} \ln$ Band 2 \\
Landsat 8 OLI/TIRS (2014) & 0.74 & $\mathrm{Y}=\ln$ Band 1+0.74*ln Band 2 \\
\hline
\end{tabular}

\section{HASIL DAN PEMBAHASAN}

\section{Sebaran dan luasan ekosistem}

Hasil interpretasi menunjukkan luasan dan penyebaran ekosistem terumbu karang dan ekosistem lamun (Gambar 2). Luasan terumbu karang sebesar $1.934,82$ ha umumnya didominasi oleh terumbu karang dengan bentuk tumbuh karang Acropora bercabang. Luasan lamun sebesar 614.43 Ha umumnya didominasi oleh jenis lamun Thallasia hemprichii, Cymodocea rotundata, Halophilla ovalis dan Halodule uninervis. Secara visual daerah terumbu karang berada pada bagian terluar dari pulau atau pada batas-batas area surut terendah sedangkan bagian tengah serta depan pulau atau area pasang surut didominasi oleh lamun dan hanya sedikit terumbu karang. Selain itu terdapat beberapa jenis makroalga yang memiliki nilai ekonomis yaitu dari genus Caulerpa, Gracilaria, Hypnea dan Eucheuma. Informasi lain terkait kondisi ekosistem di lokasi penelitian masih sangat sulit untuk diperoleh.

Hasil klasifikasi sebaran dan luasan diuji secara visual dengan melakukan pengambilan titik-titik dengan Global Position System (GPS) secara acak di lokasi penelitian yang dibandingkan dengan hasil klasifikasi citra disajikan pada Tabel 2.

Berdasarkan hasil validasi klasifikasi citra maka dari 15 titik uji yang sesuai dengan kondisi sebenarnya di lokasi penelitian adalah 10 titik sedangkan 5 titik tidak sesuai, oleh karena itu jika dirata-ratakan maka dapat dikatakan bahwa keakurasian citra berdasarkan titik uji validasi berkisar sekitar $67 \%$.

Menurut LIPI tahun 2014, batas akurasi yang dapat diterima untuk peta habitat dasar perairan dangkal berdasarkan pada SNI 7716:2011 tentang pemetaan habitat dasar perairan laut dangkal, yaitu sebesar $60 \%$. Hasil penelitian Wahiddin et al. (2014) menunjukkan bahwa keakurasian penggunaan citra landsat 8 untuk deteksi perubahan habitat terumbu karang di Pulau Morotai Maluku Utara sebesar 69\% (overall accuracy) dan dalam penelitian Aulia tahun 2015 menggunakan satelit LANDSAT 8 untuk pemetaan sebaran padang lamun mendapatkan hasil uji akurasi sebesar 70\%. Selain itu Prathama et al. (2016) menunjukkan keakurasian pemetaan sebaran padang lamun di Desa Malang Rapat dengan menggunakan citra Landsat 8 sebesar 63\%. Masoud et al. 2015 menyebutkan pemetaan habitat terumbu karang menggunakan citra satelit Landsat 8 mampu memetakan 2 sampai 4 kelas habitat terumbu karang dengan akurasi sebesar $70 \%$. Terkait dengan penjelasan tersebut Green et al. (2000) dalam menjelaskan bahwa nilai akurasi antara $60-80 \%$ dapat direkomendasikan sebagai kegiatan inventarisasi untuk pemantauan sumberdaya. 


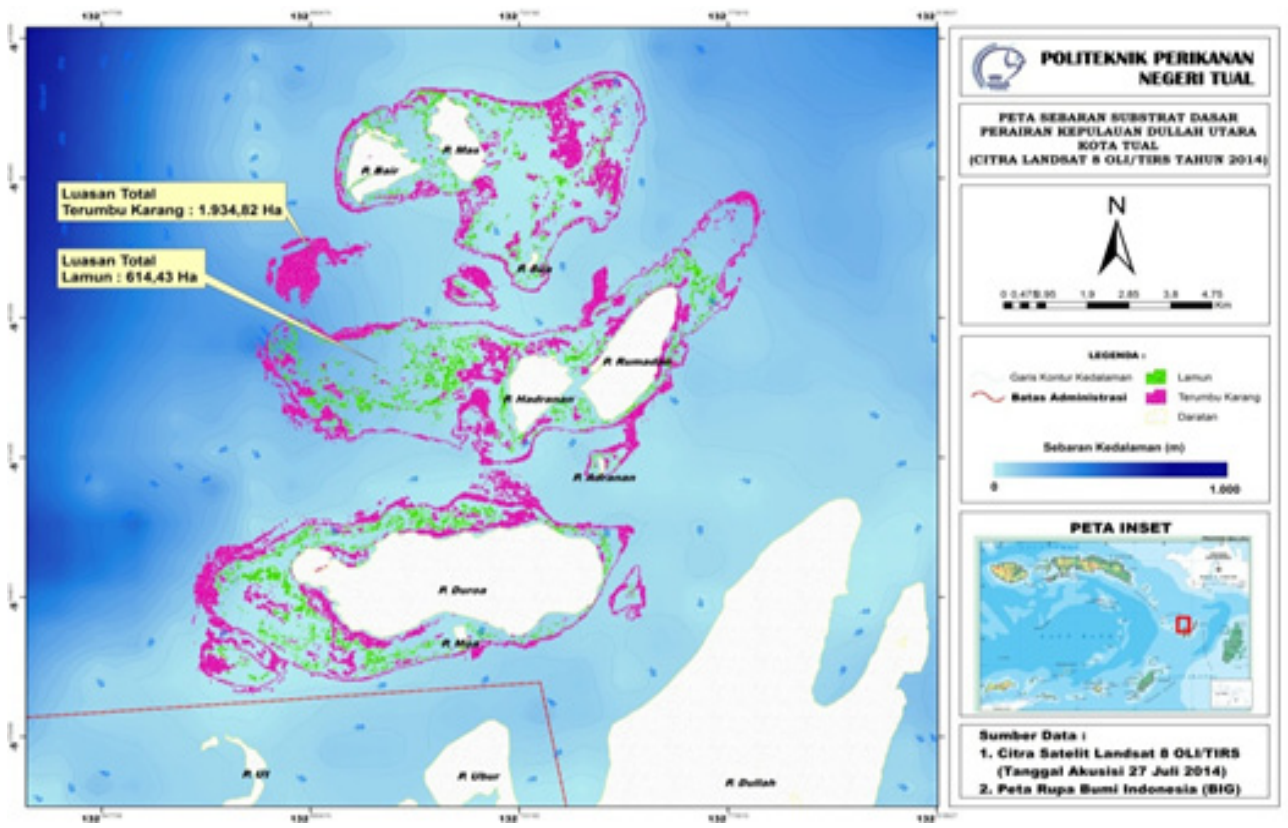

Gambar 2. Peta sebaran substrat dasar di perairan Kecamatan Dullah Utara

Tabel 2. Koordinat validasi citra Landsat 8

\begin{tabular}{ccclll}
\hline No. & $\begin{array}{c}\text { Bujur } \\
\text { Timur }\end{array}$ & $\begin{array}{c}\text { Lintang } \\
\text { Selatan }\end{array}$ & Jenis Ekosistem & Klasifikasi Citra & Keterangan \\
\hline 1. & 132.750 & -5.537 & Lamun & Terumbu Karang & Tidak Sesuai \\
2. & 132.740 & -5.530 & Lamun & Lamun & Sesuai \\
3. & 132.740 & -5.530 & Lamun & Lamun & Sesuai \\
4. & 132.732 & -5.508 & Terumbu Karang & Pasir & Tidak Sesuai \\
5. & 132.730 & -5.489 & Terumbu Karang & Terumbu Karang & Sesuai \\
6. & 132.745 & -5.493 & Lamun & Pasir & Tidak Sesuai \\
7. & 132.744 & -5.499 & Lamun & Pasir & Tidak Sesuai \\
8. & 132.750 & -5.512 & Terumbu Karang & Terumbu Karang & Sesuai \\
9. & 132.709 & -5.443 & Lamun & Lamun & Sesuai \\
10. & 132.712 & -5.452 & Terumbu Karang & Terumbu Karang & Sesuai \\
11. & 132.715 & -5.446 & Terumbu Karang & Terumbu Karang & Sesuai \\
12. & 132.698 & -5.441 & Terumbu Karang & Terumbu Karang & Sesuai \\
13. & 132.727 & -5.454 & Terumbu Karang & Terumbu Karang & Sesuai \\
14. & 132.748 & -5.515 & Terumbu Karang & Terumbu Karang & Sesuai \\
15. & 132.691 & -5.546 & Lamun & Terumbu Karang & Tidak Sesuai \\
\hline
\end{tabular}

\section{Laju perubahan ekositem terumbu karang dan lamun}

Hasil interpretasi menunjukkan perubahan yang terjadi dari kedua ekosistem dalam periode waktu 10 tahun (Gambar 3). Secara visual terlihat bertambahnya sebaran dan luasan ekosistem lamun dan terumbu karang pada periode waktu tahun 2004-2009 namun terjadi penurunan yang cukup signifikan pada periode waktu tahun 2009-2014. Statistik perubahan luasan ekosistem lamun dan terumbu karang di daerah penelitian terlihat pada Gambar 4 . 

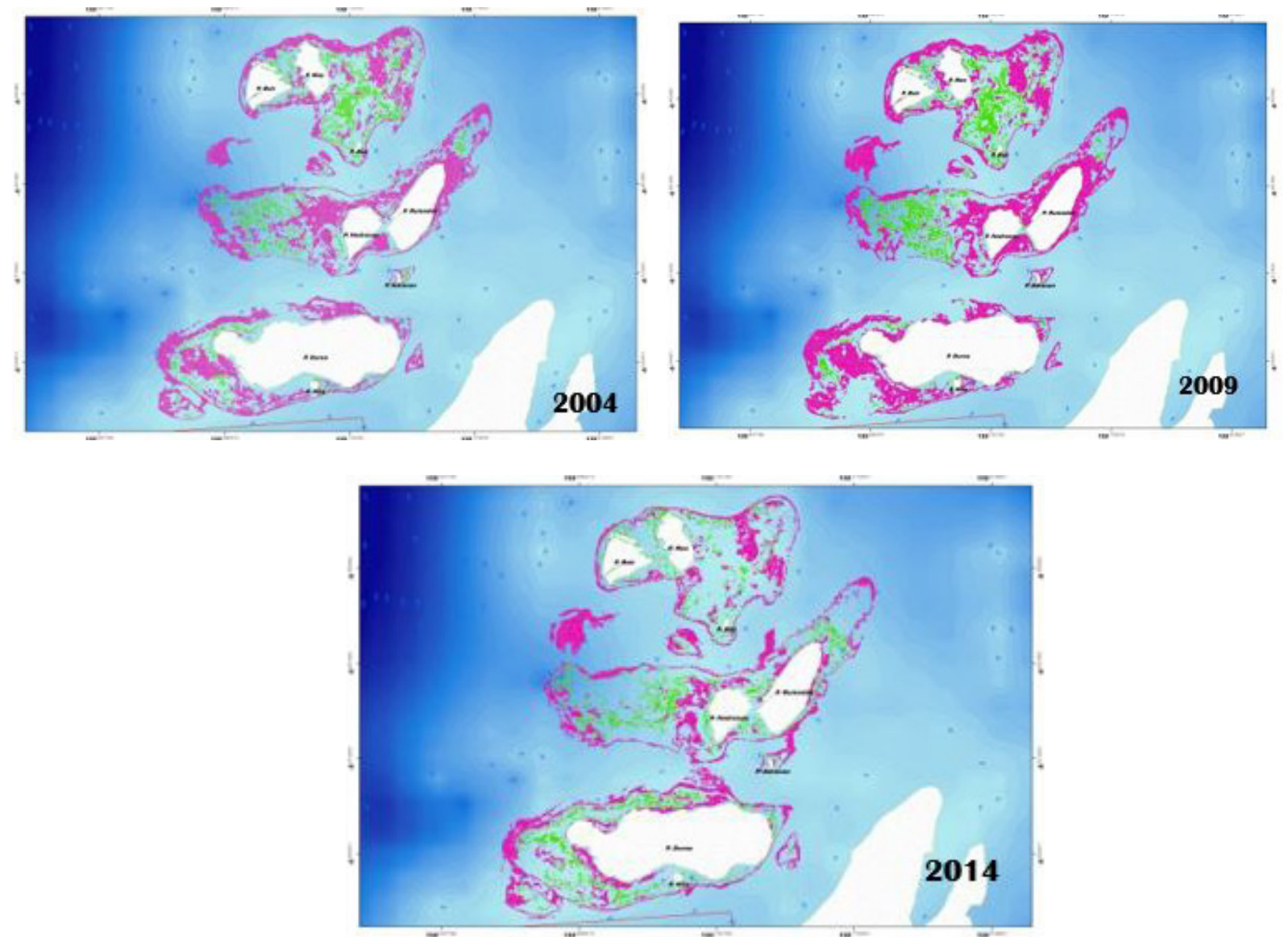

Gambar 3. Deteksi perubahan ekosistem di wilayah pesisir Kecamatan Dullah Utara

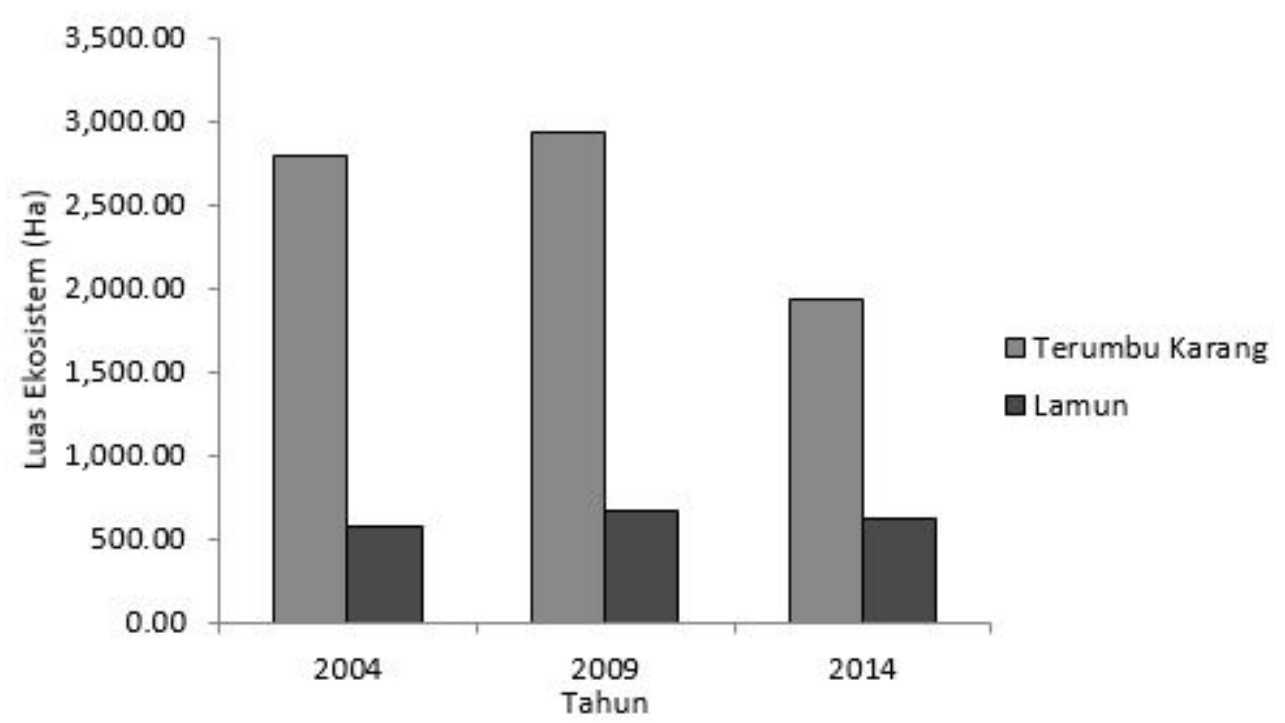

Gambar 4. Perubahan luas ekosistem terumbu karang dan lamun dari hasil analisis citra

Pertumbuhan dan penyebaran terumbu karang serta lamun sangat dipengaruhi oleh beberapa faktor antara lain parameter fisik kimia perairan, perubahan iklim secara global maupun tipe substrat, selain itu juga ekosistem inipun rentan terhadap perubahan di lahan atas akibat aktivitas manusia maupun di laut seperti penggunaan alat tangkap yang tidak ramah lingkungan.

Bertambahnya ekosistem terumbu karang dan lamun di tahun 2009 terlihat berada pada bagian sebelah Barat Pulau Duroa dan pertengahan Pulau Hadranan dan Pulau Adranan sedangkan untuk ekosistem lamun terlihat bertambah pada 
bagian Barat Pulau Hadranan dan Pulau Adranan serta diantara Pulau Mas dan Pulau Sua.

Menurut Darmadi, 2010 peningkatan pertumbuhan ekosistem terumbu karang dan lamun tidak terlepas dari beberapa faktor kualitas perairan antara lain :

Suhu

Secara global, sebaran terumbu karang dunia dibatasi oleh permukaan laut yang isoterm pada suhu $20^{\circ} \mathrm{C}$, dan tidak ada terumbu karang yang berkembang di bawah suhu $18{ }^{\circ} \mathrm{C}$. Terumbu karang tumbuh dan berkembang optimal pada perairan bersuhu rata-rata tahunan $23-25{ }^{\circ} \mathrm{C}$, dan dapat menoleransi suhu sampai dengan $36-40{ }^{\circ} \mathrm{C}$, sedangkan untuk spesies lamun kisaran suhu yang optimal untuk tumbuh yaitu 28 ${ }^{\circ} \mathrm{C}-30{ }^{\circ} \mathrm{C}$. Berdasarkan hasil pengukuran di lokasi penelitian, suhu rata-rata perairan $29.1{ }^{\circ} \mathrm{C}$ (Tabel 3) maka terumbu karang dan lamun di perairan wilayah Kota Tual dapat dikatakan memiliki pertumbuhan yang baik.

\section{Salinitas}

Terumbu karang hanya dapat hidup di perairan laut dengan salinitas air yang tetap diatas 30\% tetapi dibawah 35\% Umumnya terumbu karang tidak berkembang di perairan laut yang mendapat limpasan air tawar teratur dari sungai besar, karena hal itu berarti penurunan salinitas, sedangkan nilai salinitas yang optimum untuk lamun adalah 35\%o. Walaupun spesies lamun memiliki toleransi terhadap salinitas yang berbeda-beda, namun sebagian besar memiliki kisaran yang tinggi terhadap salinitas yaitu antara 10-30\%o. Berdasarkan hasil pengukuran perairan ini memiliki salinitas yang cukup tinggi yaitu berkisar antara 34-35\%o (Tabel 3) dengan kekeruhan yang tergolong rendah karena kurangnya masukan padatan tersuspensi dari sungai besar. Berdasarkan kondisi tersebut maka wilayah perairan ini tergolong wilayah yang mendukung pertumbuhan jenis karang maupun lamun.

\section{Cahaya dan kedalaman}

Kedua faktor tersebut berperan penting untuk kelangsungan proses fotosintesis oleh zooxanthella yang terdapat di jaringan terumbu karang. Terumbu yang dibangun karang hermatipik dapat hidup di perairan dengan kedalaman maksimal 50-70 m, dan umumnya berkembang di kedalaman 25 $\mathrm{m}$ atau kurang. Titik kompensasi untuk

Tabel 3. Hasil pengukuran suhu, salinitas, kedalaman dan kecerahan di 5 stasiun pengamatan

\begin{tabular}{lcccc}
\hline & Suhu & Salinitas & Kedalaman & Kecerahan \\
\hline Stasiun 1 & 27.6 & 34 & 16 & $100 \%$ \\
Stasiun 2 & 29.4 & 34 & 7 & $100 \%$ \\
Stasiun 3 & 29.5 & 34 & 12 & $100 \%$ \\
Stasiun 4 & 29.5 & 35 & 10 & $100 \%$ \\
Stasiun 5 & 29.5 & 34 & 10 & $100 \%$ \\
\hline
\end{tabular}

karang hermatipik berkembang menjadi terumbu adalah pada kedalaman dengan intensitas cahaya $15-20 \%$ dari intensitas di permukaan. Lamun hidup pada daerah perairan dangkal yang masih dapat dijumpai sampai kedalaman $40 \mathrm{~m}$ dengan penetrasi cahaya yang masih baik. Berdasarkan hasil pengamatan di lapangan kecerahan perairan rata-rata di lokasi penelitian berkisar pada kedalaman $11 \mathrm{~m}$ (Tabel 3), hal ini dipengaruhi juga oleh tidak adanya masukan padatan tersuspensi dari sungai besar disekitar. Untuk pertumbuhan dan perkembangan terumbu karang dan lamun, nilai suhu, salinitas, kecerahan masih sesuai untuk menunjang perkembangan kedua ekosistem tersebut.

Tahun 2014 terlihat penurunan kedua ekosistem yang cukup signifikan dibandingkan pada tahun 2009 dan 2004. Ekosistem terumbu karang dan lamun yang berada pada daerah pasang surut diasumsikan mengalami kehilangan/ kerusakan yang cukup besar hampir di seluruh area kedelapan pulau. Berdasarkan data statistik, luasan area terumbu karang pada tahun 2004, 2009 dan 2014 berturutturut sebesar 2.793,42 ha, 2.926,98 ha, dan 1.934 ha sedangkan untuk ekosistem lamun luasan ekosistem pada tahun 2004, 2009 dan 2014 berturut-turut sebesar 580.95 ha, 665.64 ha, dan 614.43 ha (Gambar 4). 
Total area keseluruhan ekosistem terumbu karang yang mengalami peningkatan luasan pada tahun 2004 ke 2009 adalah sebesar 133.56 ha (4.78\%), sedangkan ekosistem lamun mengalami peningkatan luasan sebesar 84.69 ha (14.58\%). Tahun 2009 ke 2014 ekosistem terumbu karang mengalami penurunan luasan sebesar 992.16 ha (33.89\%) sedangkan untuk ekosistem lamun mengalami penurunan luasan sebesar 51.21 ha (7.69\%). Berdasarkan hasil pengamatan visual di lapangan ada 2 hal yang menyumbang kehilangannya terumbu karang di sekitar lokasi penelitian yaitu :

1. Pemutihan karang (coral bleaching). Hasil pengamatan menunjukkan beberapa area di lokasi penelitian mengalami kondisi pemutihan karang (Gambar 5). Menurut Soeharsono (2016) terjadinya bleaching dikarenakan suhu air mengalami peningkatan hingga 2 sampai 3 derajat di atas normal, dimana suhu air laut yang selalu stabil, saat ada perubahan suhu tingkat stabilitas akan terganggu. Kemudian, efek yang timbul adalah terancamnya terumbu-terumbu karang yang ada seluruh perairan di Indonesia. Perubahan suhu air akibat El Nino di Indonesia sudah cukup sering terjadi yaitu pada tahun 1982, 1997, 1998 dan 2010. Pada tahun 2010 minimal 11 propinsi dilaporkan telah terkena bleaching NAD, Sumbar, Jatim, Bali, Sulsel, Sultra, Sulteng, NTB, Papua Barat dan Maluku (National Geographic, 2016).

2. Pengunaan alat tangkap tidak ramah lingkungan seperti bom dan bius. Berdasarkan hasil wawancara menunjukkan bahwa umumnya masyarakat nelayan disekitar area penelitian menggunakan alat tangkap yang tidak ramah lingkungan seperti bius dan bom yang mulai berlangsung pada tahun 2004 sampai saat ini, bahkan menurut informasi masyarakat bunyi bom terdengar hampir setiap hari pada beberapa tahun yang lalu. Hasil pengamatan visual di lapangan beberapa lokasi mengalami kerusakan terumbu yang diduga akibat penggunaan bom. Bom yang digunakan masyarakat umumnya berupa botol bekas seperti botol minuman suplemen diisi belerang dan pottasium sianida dengan tujuan penangkapan ikan pelagis yang bergerombol. Menurut Tatang (2015) botol bom yang terbuat dari minuman suplemen umumnya digunakan mengebom ikan dalam jumlah yang kecil mulai 1-5 kuintal ikan. Sedangkan botol bom yang terbuat dari botol bir dipakai untuk mengebom ikan dalam jumlah yang besar hingga berton-ton. Satu bom seukuran botol minuman suplemen mampu mematikan ikan hingga radius $15 \mathrm{~m}$ dari titik pengeboman sedangkan yang seukuran botol bir radiusnya $50 \mathrm{~m}$ dari titik pengeboman. Selain bom, bius juga sering digunakan oleh sejumlah nelayan, bius yang digunakan umumya diambil dari sejenis kayu yang disebut kayu bore. Kayu tersebut ditumbuk kemudian getahnya diambil dan digunakan untuk membius ikan.

Berdasarkan hasil pemetaan partisipatif masyarakat (Gambar 6) dikelompokkan beberapa area yang dikategorikan nelayan sebagai lokasilokasi yang telah mengalami kerusakan ekosistem terumbu. Area kerusakan tersebut disebabkan penggunaan alat tangkap seperti bom atau bius. Menurut Garzali (2014) penggunaan bahan peledak dan racun dalam penangkapan ikan karang menimbulkan efek samping yang sangat besar. Selain rusaknya terumbu yang ada di sekitar lokasi pengeboman, juga dapat menyebabkan kematian organisme lain yang bukan merupakan target. Sementara praktek pembiusan dapat mematikan zooxanthella hewan penyusun karang sehingga karang menjadi berubah warna yang akhirnya mati serta ikan-ikan lainnya ikut mati yang tidak menjadi target. Oleh sebab itu, penggunaan bahan peledak (bom) dan bahan beracun (potas) berpotensi menimbulkan kerusakan yang luas terhadap ekosistem terumbu karang. 

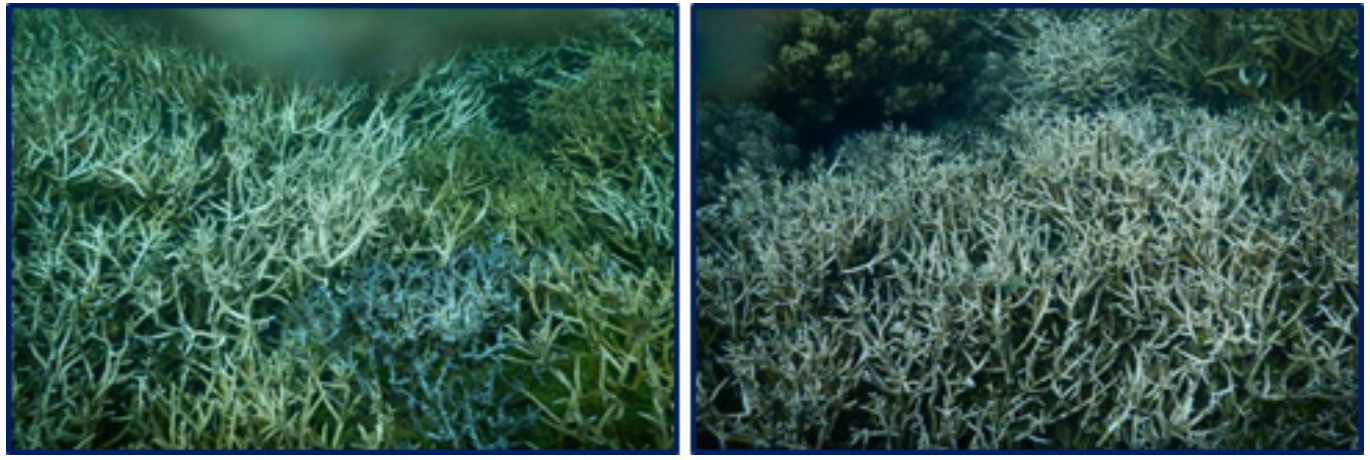

Gambar 5. Bleaching Acropora sp di perairan Kecamatan Dullah Utara

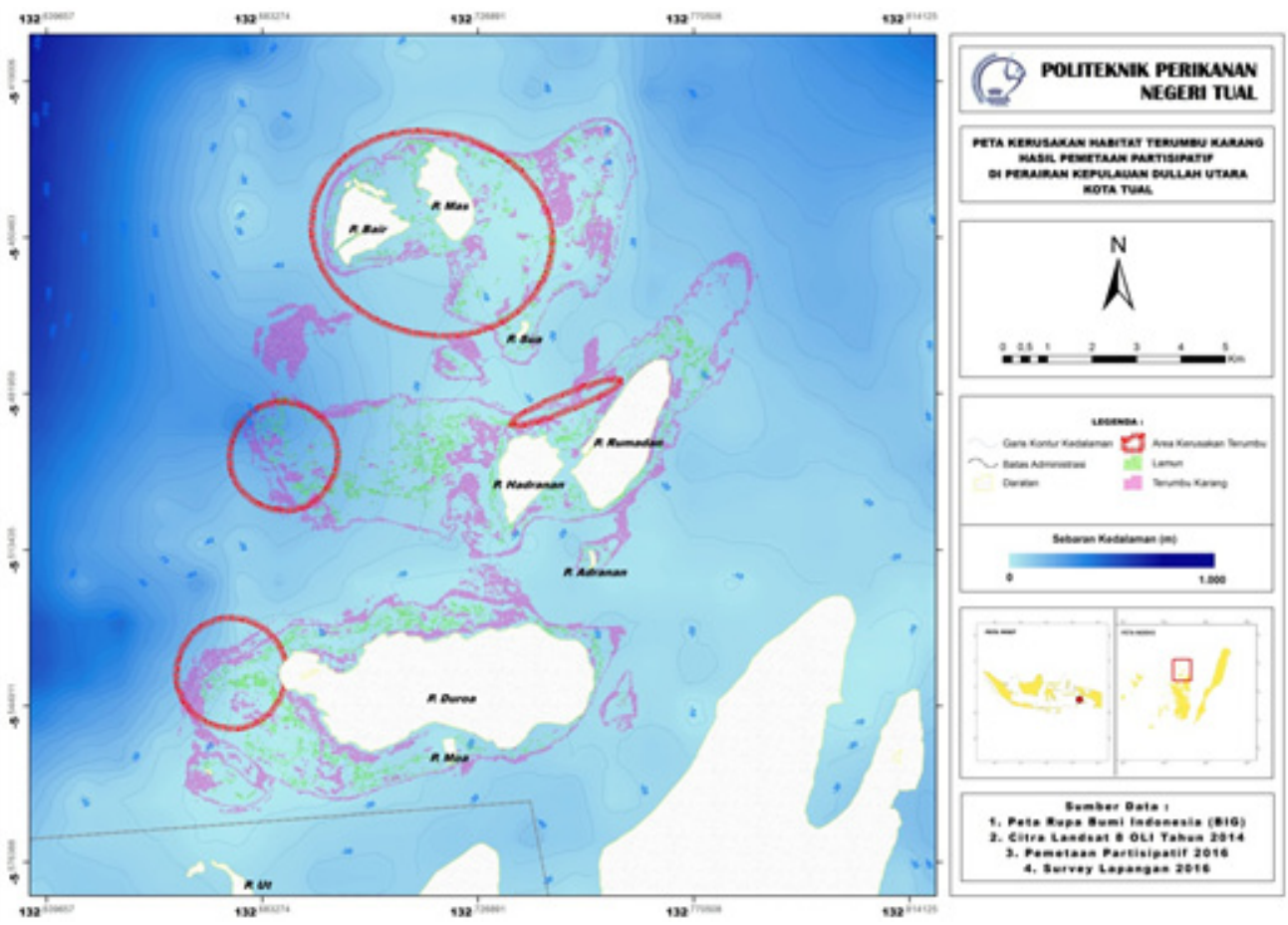

Gambar 6. Hasil pemetaan partisipatif area kerusakan terumbu karang

\section{KESIMPULAN}

Hasil interpretasi citra Landsat 8 tahun 2014 menunjukkan luasan terumbu karang di Kecamatan Dullah Utara Kota Tual sebesar $1.934,82$ ha sedangkan luasan lamun sebesar 614,43 ha.

Tahun 2004 ke 2009 terjadi peningkatan luasan ekosistem terumbu karang sebesar 133.56ha (4.78\%), sedangkan luas ekosistem lamun meningkat sebesar 84.69 ha (14.58\%). Tahun $2009 \mathrm{ke}$ 2014 ekosistem terumbu karang mengalami penurunan luas sebesar 992.16 ha $(33.89 \%)$ sedangkan untuk ekosistem lamun mengalami penurunan sebesar 51.21 ha $(7.69 \%)$

\section{DAFTAR PUSTAKA}

Aulia F. 2015. Pemetaan Sebaran Padang Lamun Di Perairan Pulau Matahari. Kecamatan Pulau Banyak. Aceh Singkil [Skripsi]. Universitas Syiah Darussalam. Banda Aceh.

Darmadi. 2010. Ekosistem Terumbu Karang di Indonesia. https://dhamadharma. wordpress.com. Diakses pada tanggal 23 Agustus 2016.

Dewanti R. 2003. Pemanfaatan Pengindraan Jauh Untuk Memantau Perubahan Hutan Bakau. Pusat Pengembangan Pemanfaatan Teknologi Pengindraan Jauh. ISSBN : 979-95466-8-0. Jakarta Timur. LAPAN. 2003

Garzali M. 2014. Menuju Industrialisasi 
Perikanan. Materi Penyuluhan : Penangkapan Ikan Yang Merusak dan Tidak Ramah Lingkungan. http:// mirsangazali.wordpress.com. Diakses pada tanggal 24 Agustus 2016.

Guntur, Prasetyo D, Wawan. (2012). Pemetaan Terumbu Karang, Teori, Metode dan Praktik. Cetakan I. Ghalia Indonesia. Bogor.

Green E, Edwards AJ, and Clark C. 2000. Remote Sensing Handbook For Tropical Coastal Management. Unesco Pub. Paris.

Hariyanto T, Lingga A, 2016. Analisa Perubahan Luasan Terumbu Karang Dengan Metode Penginderaan Jauh (Studi Kasus: Pulau Menjangan, Bali).

Helmi M, Hartoko A, Herkiki S, Munasik, Wouthuyzen S. 2011 Analisis Respon Spektral dan Ekstraksi Nilai Spektral Terumbu Karang pada Citra Digital Multispektral Satelit ALOS-AVNIR di Perairan Gugus Pulau Pari, Kepulauan Seribu, Jakarta. Buletin Oseanografi Marina. Volume I 120-136. ISSN 20893507.

Masoud AC, Mehdi M, Mohammadjavad V, Mehdi. 2015. Accuracy Assessment of the Coral Reef Mapping Using Landsat-8 Imagery- Case Study: Persian Gulf. Oceanography/Vol.6/ No.24/Winter 2015/1/10-10.

Pramudya FS, Wikantika K, Windupranata W. 2014. Satellite-Based Benthic Habitat Mapping Using LANDSAT 8 in Nusa Lembongan and Nusa Ceningan Island. Faculty of Earth Science and Technology. Institut Teknologi Bandung.

Prathama R, Dwirama R, Putra, Zulfikar A. 2016. Pemetaan Sebaran Padang Lamun Menggunakan Citra Satelit Landsat 8 Di Desa Malang Rapat Kecamatan Gunung Kijang Kabupaten Bintan. http://jurnal.umrah.ac.id.
Diakses pada tanggal 23 Agustus 2016.

Pusat Penelitian Oseanografi Lembaga Ilmu Pengetahuan Indonesia. 2014. Panduan Teknis Pemetaan Habitat Dasar Perairan Laut Dangkal. CRITC COREMAP II LIPI. Jakarta.

Sirajuddin H, Burhanuddin S, Baja S. 2010. Analisis Perubahan Morfologi Pulau Kodingareng Keke Berdasarkan Interpretasi Citra Landsat dan SPOT. http://pasca.unhas.ac.id/jurnal. Diakses pada tanggal 23 Agustus 2016.

Soeharsono. 2016. Waspadalah, Pemutihan Terumbu Karang Kini Sedang Berlangsung. http://mongabay.co.id. Diakses pada tanggal 23 Agustus 2016.

Sulma S, Winarso G. 2003. Pemanfaatan pengindraan Jauh Untuk Pemetaan Terumbu Karang. PusatPengembangan Pemanfaatan Teknologi Pengindraan Jauh. ISSBN : 979-95466-8-0. Jakarta Timur. LAPAN. 2003.

Tatang. 2015. Penangkapan Ikan Yang Merusak Ekosistem Laut. http:// suksesmina.wordpress.com. Diakses pada tanggal 23 Agustus 2016.

Wahidin N, Siregar VP, Nababan B, Jaya I, Wouthuyzen S. 2014. Deteksi Perubahan Habitat Terumbu Karang Menggunakan Citra Landsat di Pulau Morotai Provinsi Maluku Utara. Jurnal Ilmu dan Teknologi Kelautan Tropis, Vol. 6, No. 2, Hlm. 507-524, Desember 2014. @Ikatan Sarjana Oseanologi Indonesia dan Departemen Ilmu dan Teknologi Kelautan, FPIK-IPB 507.

Yulius, Novianti N, Arifin T, Hadiwijaya L, Salim, Ramdhan M, Purbani D. 2015. Distribusi Spasial Terumbu Karang Di Perairan Pulau Wangi-Wangi, Wakatobi. Jurnal Ilmu dan Teknologi Kelautan Tropis. Vol. 7, No. 1. 